Comparative Population Studies

Vol. 40, 3 (2015): 229-250 (Date of release: 25.06.2015)

\title{
Partner Market Opportunities and Relationship Stability
}

\author{
Ingmar Rapp, Thomas Klein, Sebastian Fronk, Johannes Stauder
}

\begin{abstract}
Although partner market opportunities are generally considered to be important for relationship stability, they have never been measured accurately. In order to be able to test the anticipated effects of partner market opportunities, this study conceptualises them as individual opportunities for contact and interaction in concrete social contexts, like the neighbourhood, the workplace, leisure activities, etc. Using data from the German Marriage Market Survey, we first examine the impact of individual partner market opportunities on the risk of separation. Second, we examine to what extend the most frequently studied determinants of divorce and separation depend on partner market opportunities. Our results show that the number of opposite sex contacts increases the probability of separation. Sharing the same contacts with one's partner decreases the risk of separation. Our results indicate further that reducing opposite sex contacts in the course of the relationship is partly responsible for the higher stability of longer-lasting relationships. Having a migration background is associated with fewer opposite sex contacts. This means that having a migration background would be more destabilising if these individuals did not have less opposite sex contacts than individuals without a migration background. In contrast, joint home ownership, church attendance, higher education and residing in western Germany would generally be more stabilising if these factors were not connected with more opposite sex contacts.
\end{abstract}

Keywords: Marriage market · Partner market - Relationship stability · Divorce · Separation

\section{Introduction}

Using a social exchange framework, Lewis and Spanier (1979) suggested that the stability of a relationship does not only depend on the quality of the relationship itself, but also on external pressures to remain partnered and on alternative attractions (e.g. an alternative partner). Low quality relationships may be quite stable as long as there are few alternatives and high barriers to dissolution. In contrast, 
even couples who find their relationship rewarding may separate if their perceived alternatives are better and if the barriers are low (Lewis/Spanier 1979: 287-288). In a similar way and based on an economic approach, Becker, Landes and Michael (1977: 1142) assumed that "couples separate when the utility expected from remaining married falls below the utility expected from divorcing and possibly remarrying". Again, relationship stability does not only depend on the gain from the current relationship, but also on the perceived costs of separation and on the perceived opportunities on the partner market. To summarise, the most commonly used theories of relationship stability consider partner market opportunities as an important factor in explaining marital and non-marital separations.

Despite their importance for explaining relationship (in-) stability, only few studies examined the influences of partner market opportunities on the risk of separation. Previous studies showed that unbalanced sex ratios - which indicate that at least one partner has numerous alternatives - are associated with higher risks of separation. This applies to unbalanced sex ratios in the whole society (Klein 1995) as well as to unbalanced sex ratios in local marriage markets (South/Lloyd 1995; South et al. 2001) and at the workplace (Åberg 2009; McKinnish 2004, 2007; South et al. 2001; Svarer 2007). White and Booth (1991) reported that better perceived remarriage prospects reduce marital stability. The same applies for measures of perceived alternatives that consider both the prospect of re-partnering and of being single (Felmlee et al. 1990; Udry 1981). In sum, previous studies underlined the importance of partner market opportunities in explaining relationship stability. However, only crude measures of individual's opportunities to establish a new relationship (such as perceived remarriage prospects) were used.

This study uses data from the German Marriage Market Survey which allows for a more accurate measurement of partner market opportunities. By assessing and aggregating the opportunities for contact and interaction from concrete social contexts in which heterosexual individuals are embedded, the German Marriage Market Survey offers a very detailed picture of (heterosexual) individuals' partner market opportunities. On this basis, we first examine the impact of various aspects of individual partner market opportunities on the risk of separation. In this regard, the supply of opposite sex contacts and their availability on the partner market will be considered. Moreover, the occasions for communication with potential alternative partners and the fluctuation of contact opportunities will be included. Additionally, it will also be taken into account whether contacts are shared with the partner or not. Second, our analysis turns to frequently studied determinants of divorce and separation (relationship duration, the existence of children, joint home ownership, relationship status, age at the start of the relationship, employment status, educational attainment and church attendance), and to the question whether and how these factors are linked to partner market opportunities. 


\section{A concept of partner market opportunities}

In this paper, the partner market is conceptualised as a market of potentially suitable partners for intimate (and in our case: heterosexual) relationships. Individuals' opportunities for finding a new partner are restricted, first, by the macrostructural distribution of social positions and, second, by mesostructural aspects of individuals' immediate social environment (Stauder 2008).

\section{Theoretical concepts}

The basic idea of Blau's macrostructural theory is that the social differentiation of a population forms patterns of individuals' relationships because the opportunities for contact with other individuals occupying certain social positions are constrained by the macrostructural distribution of these social positions and by relative group sizes (Blau 1977a: 40, 1977b). But macrostructural conditions will influence real contact opportunities only when the individual's social environment - the "substructures" (s)he is embedded in - actually represents the macrostructure (Blau 1977a: 46-50, 1994: 144-145; Schwartz 1990).

Individuals do not only participate in one substructure, but in many different "foci of activity" (Feld 1981). Feld (1981: 116) defines foci as social, psychological, legal or physical entities around which joint activities are organised (e.g. workplaces, voluntary associations, hangouts, families). Since social activities are organised around foci, individuals do not meet completely randomly within the constraints of a given macro-social structure. Relative group sizes within substructures will depend heavily on the specific organisational needs of the focal social activity. A focal activity may attract individuals with attributes relevant for the respective activity and thus enforce characteristic distributions of attributes within this context (Feld 1982; see also Fischer et al. 1977; Marsden 1990). For example, many jobs require contact with both men and women (as co-workers or clients); by contrast, other jobs and especially many voluntary associations are segregated by sex (Popielarz 1999). This concept of contact opportunities is confined to an individual's immediate social environment, i.e. those foci of activity which the individual is actually affiliated with. Hence, in contrast to Blau's macrostructural perspective, contact opportunities in an individual's social environment can be counted and their absolute number will vary across society members. But the sheer (co-) presence of relevant other individuals (the quantitative opportunities for contact) is only a necessary condition for the emergence of relationships within a focus. In addition, the probability of a new relationship between two individuals depends on the extent of positively valued interaction produced within the focus (Feld 1981, referring to Homans 1950).

Interaction with other individuals can provide important resources for individual action. In the literature, these resources are conceptualised as social capital. Following Esser (2000: 241-260), two forms of social capital can be distinguished: "relational capital" and "system capital". "Relational capital" results from those resources controlled by others in a network and may eventually be mobilised in favour of the realisation of ego's goals. By contrast, "system capital" refers to emergent 
properties of a network or focus, for instance the existence and amount of social control, trust or enforcement and adherence to norms.

Based on this distinction, Blau's structural theory and Feld's concept of foci of activity, the actor's social environment can be conceptualised as a set of potential relational capital that forms the space of opportunity for the development of new relationships. Against this background, opportunities for contact and opportunities for interaction can be distinguished (Stauder 2008, 2014a).

\section{Opportunities for contact}

Opportunities for contact refer to the total number of regular contacts in the individual's foci of activity and the social composition of those contacts. They should be regarded as the "potential" relational capital of an actor. Although contact opportunities essentially are a macro-sociological concept, it is possible to use this concept within the individualistic model of sociological explanation if we consider contact opportunities as potential relational capital. In order to conceptualise opportunities for contact, first, bridging assumptions about the potential relational capital of the relationships eventually emerging from a focus must be formulated. Only with these assumptions it can be determined which dimensions within the so-called Blau-space of social positions (Blau 1977b: 28) are relevant and shall be analysed. Regarding a specific goal of interaction, an ego will look for alters ${ }^{1}$ with desirable traits that are suitable for attaining that goal. All suitable alters sum up to the potential relational capital of ego, the actor. In other words, we have to consider the alters' relevance regarding the specific goal of interaction. In terms of heterosexual intimate relationships, it is clear that only people of the opposite sex are relevant. Off course, there might be many other traits of relevance, like age, education or the favourite football team. Second, if individuals are looking for a (new) partner, they have to evaluate whether relevant, i.e. opposite sex contacts, are available for an intimate relationship. In many cultures, choosing a partner is the starting point of a highly exclusive relationship. And people who already maintain an exclusive intimate relationship are only available for a new exclusive relationship within narrow limits (Stauder 2006). Thus, the chance to meet a potential (new) intimate partner varies by the number of opposite sex contacts and by their commitment in intimate relationships.

\section{Opportunities for interaction}

Whether or not opportunities for contact can turn into opportunities for interaction depends on the foci's potential to transform mere contact opportunities into interaction. Those properties of a focus that foster this transformation task can be called

1 The terms "ego" and "alter(s)" are not used in the usual sense here. "Ego" denotes the individual whose action shall be analysed; "alters" are all people sharing at least one focus of activity with ego, regardless of whether there is a tie (a relationship) between ego and alter or not. 
system capital. Foci vary to the extent they provide system capital. For example, they vary according to patterns of communication, fluctuation of participants and norms.

The activity organised around a focus may require certain patterns of communication and may impede others. There may be patterns of communication within a focus that foster interaction and the development of a relationship (high efficiency to transform opportunities for contact into opportunities for interaction). However, there may also be patterns of communication that obstruct interactions (low transformative efficiency). ${ }^{2}$

Social activities organised around foci require different degrees of regular participation. If there is no fluctuation of a focus' participants, the opportunities to establish relationships in this focus are restricted to the current participants. Hence, if there is more fluctuation, the focus provides better opportunities for interaction with novel contacts (high transformative efficiency). On the other hand, if the participants of a focus change very rapidly, there are fewer opportunities for repeated interaction after the first contact; therefore, the consolidation of interaction and the development of a relationship might be obstructed (low transformative efficiency).

The norms that apply within a focus may encourage or obstruct the development of a special kind of interaction and a resulting relationship. If interaction in the focus is highly regulated and norms obstruct any interaction that is not congruent with the focal activity, the focus is not suitable for establishing a dyadic relationship. When analysing relationship instability, social norms about the exclusivity and stability of intimate relationships will especially obstruct the development of a new intimate relationship if the current partner takes part in ego's social activities. If a couple mainly shares the same contacts, flirting with these contacts will not stay secret and is widely controlled and negatively sanctioned by the current partner and by others in the focus. Especially, potential new partners might restrain themselves from destroying ego's relationship with his or her current partner. As shared friends feel committed to both partners, the impact of such norms will particularly obstruct finding a new partner within a shared network of friends and acquaintances. ${ }^{3}$

2 This list is the result of a conceptualisation by Stauder (2014a). It does not claim to be exhaustive.

3 Visiting online dating portals grows more and more popular in many countries. Given this concept of a partner market, online dating portals are virtual foci of activity with special properties that help to find an intimate partner: Those portals can be accessed at low cost, people accessing the portal are potentially available for an intimate relationship, relevant information about potential partners is readily available (but not necessarily true), communication of the members is supposed to be focused on relevant information for partner choice, there are no norms that obstruct forming a relationship, and there is little social control from the individuals' network because the focus is separated from the individuals' other foci. In total, online dating portals optimise potential relational capital (opportunities for contact) and provide optimal system capital for partner choice (opportunities for interaction). Nevertheless, people will only visit an online dating portal when opportunities for contact and interaction in their already existing foci of activity are inefficient to find a partner. 


\section{Further determinants of divorce and separation}

Besides partner market opportunities, there are numerous other factors affecting relationship stability. Both the social exchange framework of relationship stability and the economic approach of relationship stability expect that individuals only separate if they expect greater advantages than disadvantages from being separated (and potentially start a new relationship with someone else). If one asks for the determinants of relationship stability, one has, therefore, to look for the factors that affect the gains from being in a relationship and the costs of separation.

The costs of separation should increase in particular with investments in the relationship that will be less valuable after a separation (so called "relationshipspecific capital"). A prominent example of such investments are common children of both partners (Becker et al. 1977: 1152). After a separation, at least one of the partners usually has less contact to his children than before. As expected, numerous studies showed that common children lower the risk of separation, albeit the stabilising effect becomes weaker when the children grow older (Andersson 1997; Böttcher 2006; Heaton 1990; Kalmijn et al. 2004; Liu/Vikat 2004; Lyngstad 2004; Waite/Lillard 1991; Wu/Penning 1997) and diminishes when the children leave home (Hiedemann/Suhomlinova 1998; Klein/Rapp 2010; Sauvain-Dugerdil 2006). Besides referring to their character as "relationship-specific capital", it has been suggested that common children stabilise the relationship because the partners are more mutually dependent (Heaton 1990: 56) or because children increase the cohesion of the couple (Brines/Joyner 1999). Moreover, the causality between relationship-specific capital and relationship stability may also run in the opposite direction, because couples who anticipate dissolution may hesitate to invest in children (Becker et al. 1977: 1142).

Further examples of relationship-specific capital are material investments such as joint home ownership (Levinger 1979) as well as immaterial investments such as time spent together (Rusbult 1983: 102). It is well documented that the acquisition of joint home ownership is associated with a lower risk of dissolution (Booth et al. 1985; Brüderl/Kalter 2001; South/Spitze 1986; South 2001), and virtually all existing studies showed that this also applies to longer marriage and relationship durations (Kulu 2014; Rapp 2008). Again, there are alternative mechanisms which could also be responsible for the observed effects. For example, the higher stability of relationships of home owners may also be caused by reverse causality (Brüderl/Kalter 2001; South/Spitze 1986), and the lower dissolution risk of long-lasting relationships may also be due to learning processes of the partners (Diekmann/Mitter 1984: 129-130). When not only considering married couples, the establishment of a common household and marriage itself can also be seen as investments in relationship-specific capital. Previous studies showed that marriages are more stable than non-marital cohabitations and much more stable than dating relationships (Asendorpf 2008; Boyle et al. 2008; Kalmijn et al. 2007; Lois 2008).

Previous research identified numerous other determinants of separation (for a recent overview see Arránz Becker 2015). Among the most widely studied antecedents of dissolution are socio-economic factors such as educational attainment and 
employment. These factors produced inconsistent results, probably because the effects of education and employment changed in the past decades. Recent studies indicate that both higher education of men and - this is new - also higher education of women decrease the risk of separation (De Graaf/Kalmijn 2006; Härkönen/ Dronkers 2006; Rapp 2013). The change in women's educational effect may have several reasons (Rapp 2013: 56-57). Due to women's generally improved chances to earn a living, so-called independence effects may have become less important. Additionally, recent societal processes, like the marketisation of housework, weakened the advantage of the traditional male breadwinner and female homemaker model (Kraft/Neimann 2009: 7; Oppenheimer 1997: 450; Ott 1998: 70). Furthermore, even low educated women may have adopted more liberal attitudes towards divorce and separation with some time lag (Klages 1984: 126-127). Finally, due to the rising shares of educational participation, the remaining group of low educated women (and their relationships) may be increasingly characterised by other risk factors also relevant to relationship stability, like poor economic conditions or poor social skills (Hoem 1997: 25; Wagner 1993: 390). Turning to the role of the partners' employment status, most studies showed that men's employment reduces the probability of divorce and separation, whereas women's employment increases the dissolution risk. However, it is possible that the effect of women's employment changes in the same way as women's educational effect (Arránz Becker 2015: 541).

Previous studies consistently showed that early marriages have a higher risk of separation (Lyngstad/Jalovaara 2010; Wagner/Weiß 2003). Once again various mechanisms may be responsible for this effect. Individuals that start a (marital) relationship at a very young age were supposed to be less mature (Booth/Edwards 1985; Jalovaara 2002: 540; Lee 1977) or to be less informed about the partner market (Becker et al. 1977: 1156). Additionally, previous research showed that religiousness (Boyle et al. 2008; Kalmijn et al. 2004; Lehrer/Chiswick 1993) and religious practice (Amato/Rogers 1997; Call/Heaton 1997) decrease the risk of dissolution, presumably because religiousness increases the threshold to dissolution (Lewis/ Spanier 1979).

As can be seen from the short overview above, previous research has identified numerous factors that affect relationship stability. Often there are different mechanisms that could be responsible for the observed effects, and their relative importance is unclear. And there is yet another mechanism that may play a role for all the above mentioned antecedents of dissolution, namely differences in partner market opportunities. For example, it is obvious that being employed may provide additional contacts and therefore may improve partner market opportunities. The same may apply to church attendance. Education and age at the start of the relationship might also be connected with partner market opportunities, possibly because higher educated individuals have larger networks (Roberts et al. 2009) or because individual's partner market opportunities may affect the timing of mate choice. And finally, it is conceivable that the aforementioned investments in relationship- 
specific capital do not only affect the costs of separation, but also affect partner market opportunities. ${ }^{4}$

\section{$4 \quad$ Data and Methods}

Data

For the empirical analyses we used data of the German Marriage Market Survey (Partnermarktsurvey, see Klein et al. 2010; Woll et al. 2014). This survey comprises a random sample of 2002 heterosexual individuals of the German resident population aged 16 to 55 years. The sample has been stratified by sex, age group and region (western and eastern Germany). Respondents were first interviewed by telephone in 2009. To account for seasonal variation of the assessed social activities, the first part of the sample was collected in January, February and March 2009, the second part in June, July and August 2009. In 2012, 734 respondents could be surveyed a second time. Out of these, 560 individuals had a heterosexual relationship at the time of the first interview and may therefore be at risk of having been separated during the subsequent 3-year period. After excluding 23 cases with missing values for any of the analysed variables the remaining sample contained 537 individuals.

Based on Feld's (1981) theoretical concept of foci of activity, the German Marriage Market Survey conceptualised partner market opportunities as individual opportunities for contact and interaction in concrete social contexts, like the neighbourhood, the workplace, leisure activities, etc. (Woll et al. 2014). By assessing and aggregating the opportunities for contact and interaction from the various foci of activity in which the individual is embedded, the German Marriage Market Survey offers a very detailed picture of the individual's partner market opportunities.

\section{Measures}

The main dependent variable "dissolution of the relationship" indicates if a relationship existing at the time of the first interview has been dissolved within three years (up to the date of the second interview). It must be mentioned that the data do not allow distinguishing between relationships being dissolved by separation or by the death of the partner. Nonetheless, the sample-population is aged 16-55 years and therefore exhibits age-specific mortality rates much less than one percent (Statistisches Bundesamt 2012: 17). Therefore, "dissolution of the relationship" is a quite reliable measure of separation.

All of the following variables were assessed at the time of the first interview. Our indicators for the respondent's partner market opportunities are:

4 There may be more determinants of divorce and separation that may be connected with partner market opportunities, such as income, health and community size. Measures of these factors are, however, not available in the data. 
- "Log (number of regular opposite sex contacts)" was built by summing the number of opposite sex contacts over all foci of activity of an individual and logarithmising this sum score. Thanks to logarithmising, an additional second or third opposite sex contact is given more weight than an additional hundredth-and-second or hundredth-and-third contact, and the indicator is approximately normally distributed (see Stauder 2014b).

- "Most acquaintances are in a relationship" was measured as a dummy-variable and indicates whether the respondent agreed with the statement that most of his opposite sex acquaintances are partnered (=1, 0 otherwise).

- "Opportunities for communication" were measured by the degree of agreement with the statement "There are opportunities to have a talk with others" (mean over all foci of the respondent, possible responses were $0=$ "completely disagree" to $10=$ "completely agree").

- "Fluctuation of contact opportunities" was measured by the question "How often do you meet new people" (mean over all foci of the respondent, possible responses were $0=$ "never", 1 = "rarely", 2 = "sometimes", 3 = "often").

- "Mainly the same acquaintances as the partner" was measured as a dummyvariable and indicates if the respondent agreed with the statement that he/ she and his/her partner have "mainly" the same friends and acquaintances.

Our measures for frequently studied determinants of separation are:

- "Relationship duration" was measured in years and indicates the duration since the start of the relationship.

- "Children" indicates if the respondent cohabited with one or more biological children at the time of the first interview (=1, 0 otherwise).

- "Joint home ownership" indicates if the partners bought a shared freehold flat or a joint house ( $=1,0$ otherwise).

- Two dummy-variables show whether the couple was "married" (=1, 0 otherwise) or lived in a "non-marital cohabitation" (=1, 0 otherwise). The reference group includes couples who did not live together ("dating relationship"). All married couples were included in the "married" category regardless of whether the partners currently shared a common household or not.

- The employment status was measured using a set of three dummy-variables. "Part-time employed" indicates that the respondent was employed less than full time (including part-time employed, marginally employed, "one-Eurojob" which are public service jobs that do not affect unemployment benefits, military or civilian service or voluntary social year, occasionally employed and partial retirement). "Not employed" signalises if the respondent was neither in work (including unemployed) nor in education. "Still in education" indicates if the respondent was in education. The reference category indicates if the respondent was full-time employed.

- "Years of education" indicates the years usually required for completing the respective level of education. The degrees of the German general school system were coded as follows: no certificate $=8$ years, "Berufsschulreife" (vocational school certificate) $=9$ years, "Mittlere Reife" (equal to General Certificate of Secondary Education) = 10 years, "Fachhochschulreife" (university of applied sciences entrance certificate) = 12 years and "Hochschulreife" (university entrance certificate) $=13$ years. If an individual was still in general education this variable was set to 10 , because the respondents were at minimum 16 years old and therefore had usually already obtained "Mit- 
- Ingmar Rapp, Thomas Klein, Sebastian Fronk, Johannes Stauder

Tab. 1: Scale, mean values and standard deviations of all analysed variables

\begin{tabular}{llrl}
\hline & Scale & Mean & (SD) \\
\hline Dissolution of the relationship & $0 / 1$ & 0.11 & \\
Log (number of regular opposite sex contacts) & 0 to 6.63 & 3.48 & $(1.00)$ \\
Most acquaintances are in a relationship & $0 / 1$ & 0.89 & \\
Occasions for communication & 0 to 10 & 7.16 & $(1.94)$ \\
Fluctuation of contact opportunities & 0 to 4 & 2.72 & $(0.49)$ \\
Mainly the same acquaintances as the partner & $0 / 1$ & 0.76 & \\
Relationship duration & 0 to 39 & 17.87 & $(10.86)$ \\
Children & $0 / 1$ & 0.66 & \\
Joint home ownership & $0 / 1$ & 0.50 & \\
Relationship status & & & \\
Married & $0 / 1$ & 0.74 & \\
Non-marital cohabitation & $0 / 1$ & 0.12 & \\
Dating relationship & $0 / 1$ & 0.14 & \\
Age at the start of the relationship & 13 to 55 & 25.92 & $(8.65)$ \\
Employment status & & & \\
Full-time employed & $0 / 1$ & 0.50 & \\
Part-time employed & $0 / 1$ & 0.32 & \\
Not employed & $0 / 1$ & 0.12 & \\
Still in education & $0 / 1$ & 0.06 & \\
Years of education & 9 to 18 & 14.60 & $(2.46)$ \\
Church attendance & $0 / 1$ & 0.20 & \\
Residing in western Germany & $0 / 1$ & 0.78 & \\
Migration background & $0 / 1$ & 0.12 & \\
Man & $0 / 1$ & 0.36 & \\
\hline
\end{tabular}

SD = standard deviation

Source: own calculation based on the German Marriage Market Survey

tlere Reife". Upper secondary or tertiary educational degrees were assessed separately and set as follows: no certificate (including those still in the vocational education system) $=0$ years; apprenticeship or certificate from a vocational school $=3$ years; university $=5$ years. The variable "years of education" was then calculated by adding both generated metric variables of education.

- "Age at the start of the relationship" was measured in years and indicates the age of the respondent at the start of the relationship.

- "Church attendance" indicates if the respondent went to church at least once a month (=1, 0 otherwise). 
Our control variables are:

- "Residing in western Germany" indicates if the respondent lived in western $(=1)$ or eastern $(=0)$ Germany.

- "Migration background" indicates whether the individual or at least one of his or her parents was born abroad (=1, 0 otherwise).

- "Man" indicates if the respondent was male $(=1)$ or female $(=0)$.

Table 1 presents the scale, means and standard deviations of all analysed variables.

\section{Statistical analyses}

This study uses logit regression analyses to examine the effects of individual partner market opportunities and the effects of some frequently studied determinants of relationship stability on the probability of separation within a three year period. Different models are estimated: The first model only includes some frequently studied determinants of relationship stability; all further models also include measures of partner market opportunities. Additionally, logit and ordinary least squares (OLS) regression analyses are used to examine the impact of these frequently studied determinants of relationship stability on those individual partner market opportunities that turned out to be significant.

\section{$5 \quad$ Results}

Model 1 of Table 2 presents the effects of some frequently studied determinants of relationship stability on the risk of separation within a three year period. Of all included variables, only relationship duration and relationship status significantly affect the risk of separation. As expected, longer relationship duration and being in a non-marital cohabitation or being married reduce the odds of separation.

Models 2 to 6 of Table 2 additionally account for individual partner market opportunities of the respondent. Model 2 shows that the higher the logarithmised number of regular opposite sex contacts, the greater is the risk of separation (OR 1,59). Whether most acquaintances were in a relationship as opposed to being single does not affect relationship stability (Model 3), and the same applies to occasions for communication with the contact opportunities (Model 4) and to the fluctuation of contact opportunities (Model 5). The fact whether the respondent had mainly the same friends and acquaintances as his or her partner does not initially affect the odds of separation (Model 6). However, the effect turns significant when all partner market indicators are included in the same model (Model 7): In this case, the probability of separation is reduced significantly (OR 0,47$)$.

When comparing the effects of the determinants from Model 1 (without controlling for individual partner market opportunities) to the models that control for individual partner market opportunities, most coefficients remain similar. Nonetheless, some changes are mentionable. The effect of relationship duration on the risk of 
240 - Ingmar Rapp, Thomas Klein, Sebastian Fronk, Johannes Stauder

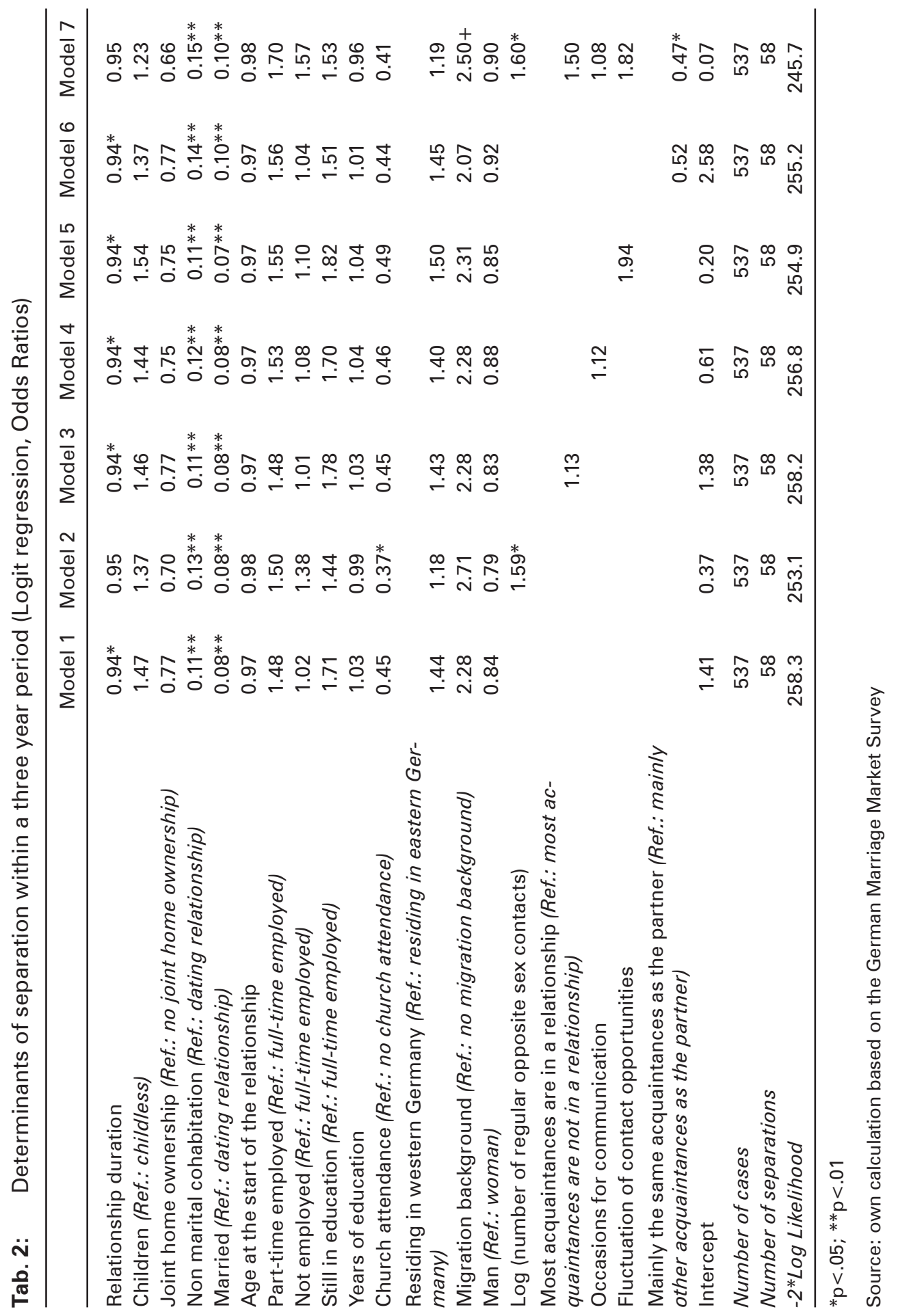


separation is weaker and no longer significant if the logarithmised number of opposite sex contacts is controlled for (compare Model 1 and 2). In contrast, the negative effect of church attendance on dissolution gets stronger and turns significant after controlling for the logarithmised number of opposite sex contacts (compare Model 1 and 2).

Tab. 3: Determinants of the logarithmised number of opposite sex contacts (OLS-regression, unstandardised regression coefficients)

\begin{tabular}{lc}
\hline Relationship duration & $-0.02^{* *}$ \\
Children (Ref.: childless) & 0.06 \\
Joint home ownership (Ref.: no joint home ownership) & $0.22^{*}$ \\
Non marital cohabitation (Ref.: dating relationship) & $-0.33^{*}$ \\
Married (Ref.: dating relationship) & $-0.37^{*}$ \\
Age at the start of the relationship & $-0.03^{* *}$ \\
Part-time employed (Ref.: full-time employed) & 0.06 \\
Not employed (Ref.: full-time employed) & $-0.52^{* *}$ \\
Still in education (Ref.: full-time employed) & 0.17 \\
Years of education & $0.09^{* *}$ \\
Church attendance (Ref.: no church attendance) & $0.24^{*}$ \\
Residing in western Germany (Ref.: residing in eastern Germany) & $0.40^{* *}$ \\
Migration background (Ref.: no migration background) & $-0.26^{*}$ \\
Man (Ref.: woman) & 0.10 \\
Intercept & $3.12^{* *}$ \\
$N$ & 537 \\
Adjusted R-Square & 0.17 \\
\hline
\end{tabular}

${ }^{*} \mathrm{p}<.05 ;{ }^{* *} \mathrm{p}<.01$

Source: own calculation based on the German Marriage Market Survey

Table 3 presents the effects of the determinants of separation from Table 2 on the logarithmised number of opposite sex contacts. Thus, multiplying the regression coefficients by 100 approximately shows the percentage change of the number of opposite sex contacts if the independent variable changes by one unit. For example, each additional relationship year reduces the number of opposite sex contacts by two percent. Results further show that being married or being in a non-marital cohabitation, having a lower age at the start of the relationship, being not employed and having a migration background also reduce the number of opposite sex contacts significantly. In contrast, joint home ownership, years of education, church attendance and residing in western Germany increase the number of opposite sex contacts. 
Table 4 presents the effects of the determinants of separation from Table 2 on the odds of having mainly the same friends and acquaintances as the partner. Being in a non-marital cohabitation (OR 4,12) or being married (OR 6,31) significantly increases whereas being in education $(O R 0,37)$ significantly reduces the probability of having mainly the same friends and acquaintances as the partner.

Tab. 4: Determinants of having mainly the same friends and acquaintances as the partner (Logit-regression, Odds Ratios)

\begin{tabular}{lc}
\hline Relationship duration & 1.01 \\
Children (Ref.: childless) & 0.62 \\
Joint home ownership (Ref.: no joint home ownership) & 1.14 \\
Non marital cohabitation (Ref.: dating relationship) & $4.12^{* *}$ \\
Married (Ref.: dating relationship) & $6.31^{* *}$ \\
Age at the start of the relationship & 0.97 \\
Part-time employed (Ref.: full-time employed) & 1.16 \\
Not employed (Ref.: full-time employed) & 0.79 \\
Still in education (Ref.: full-time employed) & $0.37^{*}$ \\
Years of education & 0.94 \\
Church attendance (Ref.: no church attendance) & 0.85 \\
Residing in western Germany (Ref.: residing in eastern Germany) & 0.86 \\
Migration background (Ref.: no migration background) & 0.57 \\
Man (Ref.: woman) & 0.92 \\
Intercept & $6.24^{*}$ \\
$N$ & 537 \\
$-2 *$ Log Likelihood & 515.8 \\
\hline
\end{tabular}

${ }^{*} \mathrm{p}<.05 ;{ }^{*} \mathrm{p}<.01$

Source: own calculation based on the German Marriage Market Survey

\section{Discussion}

The first objective of this study was to investigate the impact of individual partner market opportunities on relationship stability. Previous studies have underlined the importance of partner market opportunities in explaining relationship stability but empirical measures have only been rather general so far. As predicted in the social exchange framework (Lewis/Spanier 1979) and the economic approach of relationship stability (Becker et al. 1977), respondent's contact opportunities - measured as the (logarithmised) number of regular opposite sex contacts from the various social activities in which the individual is embedded - increased the probability of separation. This result is in line with previous research that used more crude meas- 
ures of individual partner market opportunities (Felmlee et al. 1990; Udry 1981; White/Booth 1991). Another central finding was that the risk of separation was reduced if both partners had mainly the same friends and acquaintances. Once again, this result confirms previous research (Booth et al. 1985; Kneip 2008). Further aspects of individual partner market opportunities did not significantly affect the risk of separation. In particular, our results do not support the expectation that "system capital" of social contexts, such as patterns of communication and fluctuation, affect the risk of separation. However, it is important to point out that the sample size was relatively small. Therefore, it cannot be ruled out that these factors may have substantial effects on relationship stability in a larger sample.

The second objective of this study was to examine to what extend some frequently studied determinants of divorce and separation depend on individual's partner market opportunities. Results showed that the number of opposite sex contacts decreased with increasing relationship duration, with being married or being in a non-marital cohabitation, with age at the start of the relationship, with being not employed and with having a migration background. Thus, reducing opposite sex contacts in the course of the relationship is partly responsible for the higher stability of longer-lasting relationships. When controlling for respondents opposite sex contacts, the stabilising effect of relationship duration on separation even loses significance. Similarly, a reduction of opposite sex contacts with increasing age contributes to the well-documented higher stability of couples which were older at the start of their relationships. Furthermore, the higher stability of marriages and non-marital cohabitations compared to dating relationships is partly due to the fact that married couples and cohabiting couples have fewer contact opportunities. In case of employment, it can be concluded that being not employed would be more destabilising if individuals who are not employed had the same contact opportunities like the employed. The same applies to migration background. That is, the instability of migrants' partnerships is underestimated if their reduced opposite sex contacts are not taken into account.

In addition, results showed that joint home ownership, years of education, church attendance and residing in western Germany increased the number of opposite sex contacts. Especially in case of joint home ownership and church attendance previous research consistently showed that both factors increase relationship stability (Amato/Rogers 1997; Booth et al. 1985; Brüderl/Kalter 2001; Call/Heaton 1997; South/Spitze 1986; South 2001). Therefore, our results imply that joint home ownership and church attendance would be even more stabilising if these factors were not connected with more opposite sex contacts. As to church attendance, the stabilising effect turned significant after controlling for the respondent's opposite sex contacts. Furthermore, partnerships in western Germany and among the higher educated would be more stable if these factors were not associated with more opposite sex contacts.

Further results showed that being married or being in a non-marital cohabitation increased the probability of having the same friends and acquaintances as one's partner. Apparently, a common household comes along with common contacts and this is another reason why cohabitations and marriages are more stable than dating 
relationships. In contrast, being in education reduced the probability of having the same friends and acquaintances as the partner. Thus, intimate relationships of pupils and students would be more stable if these couples would not have less shared friends and acquaintances than other couples.

Remarkably, having children did neither significantly affect the number of opposite sex contacts nor the probability of having the same friends and acquaintances as the partner. Thus, the stabilising effect of children, as often found in previous studies with larger samples as ours, cannot be explained by differences in partner market opportunities.

The current study has some limitations. First of all, the present study is based on only 537 intimate relationships of which only 58 separated within a three year period. This is the most likely reason that we, in contrast to previous studies with larger samples, did not find significant effects of children, joint home ownership, age at the start of the relationship, employment status and education on the risk of separation. Additionally, due to the small number of cases, it was not possible to consider differences between various subgroups that might be important, such as differences between men and women or between marriages, cohabitations and dating relationships. This is particularly problematic when analysing the effect of employment status on relationship stability, because previous research reported different effects between men and women and between marriages and non-marital cohabitations (Lois 2008).

Another shortfall of the current study is that the German Marriage Market Survey only comprises information on the respondent's partner market opportunities. Of course, relationship stability depends on the partner market opportunities of both partners. Furthermore, all independent variables were assessed only at the time of the first interview. Therefore, the data did not allow including time varying independent variables. Nonetheless, at least for Germany there are no data available which are better suited for analysing the impact of individual partner market opportunities on relationship stability.

In sum, our results underline the importance of individual partner market opportunities for explaining the stability of intimate relationships. Moreover, our results suggest that some familiar determinants of relationship stability that were usually discussed in terms of rewards of the current relationship and costs of separation are also connected with individual's partner market opportunities. In this regard, partner market opportunities may either partially explain effects (as it was in the case of relationship duration) or cover effects (as it was in the case of church attendance). Future research on relationship stability should, therefore, ideally also consider information on individual partner market opportunities. 


\section{References}

Áberg, Yvonne 2009: The contagiousness of divorce. In: Hedström, Peter; Bearman, Peter (Eds.): The Oxford handbook of analytical sociology. Oxford: Oxford University Press.

Amato, Paul R.; Rogers, Stacy J. 1997: A longitudinal study of marital problems and subsequent divorce. In: Journal of Marriage and the Family 59,3: 612-624 [doi: 10.2307/353949].

Andersson, Gunnar 1997: The impact of children on divorce risks of Swedish women. In: European Journal of Population 13,2: 109-145 [doi: 10.1023/A:1005803001129].

Arránz Becker, Oliver 2015: Determinanten und Konsequenzen von Trennung und Scheidung, Handbuch Familiensoziologie. Springer: 527-561.

Asendorpf, Jens B. 2008. Living apart together. Alters- und Kohortenabhängigkeit einer heterogenen Lebensform: In: Kölner Zeitschrift für Soziologie und Sozialpsychologie 60,4: 749-764 [doi: 10.1007/s11577-008-0035-4].

Becker, Gary S.; Landes, Elisabeth M.; Michael, Robert T. 1977: An Economic Analysis of Marital Instability. In: Journal of Political Economy 85: 1141-1187.

Blau, Peter M. 1977a: A Macrosociological Theory of Social Structure. In: American Journal of Sociology 83,1: 26-54 [doi: 10.1086/226505].

Blau, Peter M. 1977b: Inequality and Heterogeneity. A Primitive Theory of Social Structure. New York: Free Press.

Blau, Peter M. 1994: Structural Contexts of Opportunities. Chicago: University of Chicago Press.

Booth, Alan; Edwards, John N. 1985: Age at Marriage and Marital Instability. In: Journal of Marriage and the Family 47,1: 67-75 [doi: 10.2307/352069].

Booth, Alan, et al. 1985: Predicting divorce and permanent separation. In: Journal of Family Issues 6,3: 331-346 [doi: 10.1177/019251385006003005].

Böttcher, Karin 2006: Scheidung in Ost- und Westdeutschland. Der Einfluss der Frauenerwerbstätigkeit auf die Ehestabilität. In: Kölner Zeitschrift für Soziologie und Sozialpsychologie 58,4: 592-616 [doi: 10.1007/s11577-006-0258-1].

Boyle, Paul J. et al. 2008: Moving and union dissolution. In: Demography 45,1: 209-222 [doi: 10.1353/dem.2008.0000].

Brines, Julie; Joyner, Kara 1999: The Ties that Bind: Principles of Cohesion in Cohabitation and Marriage. In: American Sociological Review 64,3: 333-355 [doi: 10.2307/2657490].

Brüderl, Josef; Kalter, Frank 2001: The Dissolution of Marriages: The Role of Information and Marital-Specific Capital. In: Journal of Mathematical Society 25, 403-421 [doi: 10.1080/0022250X.2001.9990262].

Call, Vaughn R. A.; Heaton, Tim B. 1997: Religious influence on marital stability. In: Journal for the Scientific Study of Religion 36,3: 382-392 [doi: 10.2307/1387856].

De Graaf, Paul M.; Kalmijn, Matthijs 2006: Change and stability in the social determinants of divorce: A comparison of marriage cohorts in the Netherlands. In: European Sociological Review 22,5: 561-572 [doi: 10.1093/esr/jcl010].

Diekmann, Andreas; Mitter, Peter 1984: A Comparison of the "Sickle Function" with Alternative Stochastic Models of Divorce Rates. In: Diekmann, Andreas; Mitter, Peter (Eds.): Stochastic Modelling of Social Processes. London: Academic Press, Inc.: 123153. 
Esser, Hartmut 2000: Soziologie. Spezielle Grundlagen. Band 4: Opportunitäten und Restriktionen. Frankfurt am Main: Campus.

Feld, Scott L. 1981: The Focused Organization of Social Ties. In: American Journal of Sociology 86,5: 1015-1035 [doi: 10.1086/227352].

Feld, Scott L. 1982: Social Structural Determinants of Similarity among Associates. In: American Sociological Review 47,6: 797-801 [doi: 10.2307/2095216].

Felmlee, Diane; Sprecher, Susan; Bassin, Edward 1990: The dissolution of intimate relationships: A hazard model. In: Social Psychology Quarterly 53,1: 13-30 [doi: 10.2307/2786866].

Fischer, Claude S. et al. 1977: Networks and Places. Social Relations in the Urban Setting. New York: The Free Press.

Häder, Sabine; Gabler, Siegfried 1998: Ein neues Stichprobendesign für telefonische Umfragen in Deutschland. In: Gabler, Siegfried; Häder, Sabine; Hoffmeyer-Zlotnik, Jürgen H. P. (Eds.): Telefonstichproben in Deutschland. Opladen: Westdeutscher Verlag: $69-88$

Härkönen, Juho; Dronkers, Jaap 2006: Stability and change in the educational gradient of divorce. A comparison of seventeen countries. In: European Sociological Review 22,5: 501-517 [doi: 10.1093/esr/jcl011].

Heaton, Tim B. 1990: Marital Stability Throughout the Child-Rearing Years. In: Demography 27,1: 55-63 [doi: 10.2307/2061552].

Hiedemann, Bridget; Suhomlinova, Olga; O'Ran, Angela M. 1998: Economic Independence, Economic Status, and Empty Nest in Midlife Marital Duration. In: Journal of Marriage and the Family 60,1: 219-231 [doi: 10.2307/353453].

Hoem, Jan M. 1997: Educational Gradients in Divorce Risks in Sweden in Recent Decades. In: Population Studies 51,1: 19-27 [doi: 10.1080/0032472031000149696].

Homans, George C. 1950: The Human Group. New York: Harcourt, Brace \& World.

Jalovaara, Marika 2002: Socioeconomic Differentials in Divorce Risk by Duration of Marriage. In: Demographic Research 7: 537-564 [doi: 10.4054/DemRes.2002.7.16].

Kalmijn, Matthijs; De Graaf, Paul M.; Poortman, Anne-Rigt 2004: Interactions between cultural and economic determinants of divorce in the Netherlands. In: Journal of Marriage and Family 66,1: 75-89 [doi: 10.1111/j.1741-3737.2004.00006.x].

Kalmijn, Matthijs; Loeve, Anneke; Manting, Dorien 2007: Income dynamics in couples and the dissolution of marriage and cohabitation. In: Demography 44,1: 159-179 [doi: 10.1353/dem.2007.0005].

Klages, Helmut 1984: Wertorientierungen im Wandel. Rückblick, Gegenwartsanalyse, Prognosen. Frankfurt am Main/New York: Campus.

Klein, Thomas 1995: Heiratsmarkt und 'Marriage Squeeze'. In: Nauck, Bernhard; OnnenIsemann, Corinna (Eds.): Familie im Brennpunkt von Wissenschaft und Forschung. Neuwied: Luchterhand: 357-368.

Klein, Thomas; Rapp, Ingmar 2010: Der Einfluss des Auszugs von Kindern aus dem Elternhaus auf die Beziehungsstabilität der Eltern. In: Zeitschrift für Soziologie 39,2: 140150.

Klein, Thomas; Stauder, Johannes; Häring, Armando 2010: Gelegenheiten des Kennenlernens - der Partnermarkt in Ost- und Westdeutschland. In: Krause, Peter; Ostner, Ilona (Eds.): Leben in Ost- und Westdeutschland. Eine sozialwissenschaftliche Bilanz der deutschen Einheit 1990-2010. Frankfurt/New York: Campus: 187-209. 
Kneip, Thorsten 2008: Soziale Einbettung und partnerschaftliche Stabilität. Der Einfluss partnerschaftsspezifischen Sozialkapitals. In: Feldhaus, Michael; Huinink, Johannes (Eds.): Neuere Entwicklungen in der Beziehungs- und Familienforschung. Würzburg: Ergon: 431-457.

Kraft, Kornelius; Neimann, Stefanie 2009: Effect of labor division between wife and husband on the risk of divorce: Evidence from German data. SOEPpapers on Multidisciplinary Panel Data Research, No. 223: 1-31.

Kulu, Hill 2014: Marriage duration and divorce: the seven-year itch or a lifelong itch? In: Demography 51,3: 881-893 [doi: 10.1007/s13524-013-0278-1].

Lee, Gary R. 1977: Age at Marriage and Marital Satisfaction: A Multivariate Analysis with Implications for Marital Stability. In: Journal of Marriage and the Family 39,3: 493-504 [doi: 10.2307/350904].

Lehrer, Evelyn L.; Chiswick, Carmel U. 1993: Religion as a determinant of marital stability. In: Demography 30,3: 385-404 [doi: 10.2307/2061647].

Levinger, George 1979: A social Psychological Perspective on Marital Dissolution. In: Levinger, George; Moles, Oliver C. (Eds.): Divorce and Separation. New York: Basic Books: 37-60.

Lewis, Robert A.; Spanier, Graham B. 1979: Theorizing about the Quality and Stability of Marriage. In: Burr, Wesley R. et al. (Eds.): Contemporary Theories about the Family. Vol. 1. New York: The Free Press: 268-294.

Liu, Guiping; Vikat, Andres 2004: Does divorce risk depend on spouses' relative income? A register-based study of first marriages in Sweden in 1981-1998. MPIDR Working Paper, WP 2004-010: 1-23.

Lois, Danie/ 2008: Arbeitsteilung, Berufsorientierung und Partnerschaftsstabilität Ehen und nichteheliche Lebensgemeinschaften im Vergleich. In: Kölner Zeitschrift für Soziologie und Sozialpsycholgie 60,1: 53-77 [doi: 10.1007/s11577-008-0003-z].

Lyngstad, Torkild H. 2004: The impact of parents' and spouses' education on divorce rates in Norway. In: Demographic Research 10: 121-142 [doi: 10.4054/DemRes.2004.10.5] .

Lyngstad, Torkild H.; Jalovaara, Marika 2010: A review of the antecedents of union dissolution. In: Demographic Research 23: 257-292 [doi: 10.4054/DemRes.2010.23.10].

Marsden, Peter V. 1990: Network Diversity, Substructures, and Opportunities for Contact. In: Calhoun, Craig; Meyer, Marshall W.; Scott, Richard W. (Eds.): Structures of Power and Constraint: Papers in Honor of Peter M. Blau. Cambridge: Cambridge University Press: 397-410.

McKinnish, Terra G. 2004: Occupation, sex-integration, and divorce. In: American Economic Review 94,2: 322-325 [doi: 10.1257/0002828041301911].

McKinnish, Terra G. 2007: Sexually Integrated Workplaces and Divorce: Another Form of On-the-Job Search. In: Journal of Human Resources 42,2: 331-352.

Oppenheimer, Valerie K. 1997: Women's employment and the gain to marriage: The specialization and trading model. In: Annual review of sociology 23: 431-453 [doi: 10.1146/ annurev.soc.23.1.431].

Ott, Notburga 1998: Der familienökonomische Ansatz von Gary S. Becker. In: Pies, Ingo; Leschke, Martin (Eds.): Gary Beckers ökonomischer Imperialismus. Tübingen: Mohr Siebeck: 63-90.

Popielarz, Pamela A. 1999: (In) Voluntary Association: A Multilevel Analysis of Gender Segregation in Voluntary Organizations. In: Gender and Society 13,2: 234-250 [doi: 10.1177/089124399013002005]. 
Rapp, Ingmar 2008: Wann werden Ehen getrennt? Der Einfluss der Ehedauer auf das Trennungsrisiko. In: Kölner Zeitschrift für Soziologie und Sozialpsychologie 60,3: 500527 [doi: 10.1007/s11577-008-0025-6].

Rapp, Ingmar 2013: Ehestabilität in der zweiten Lebenshälfte. Eine Analyse von kumulierten sozialwissenschaftlichen Umfragedaten. Wiesbaden: Springer-VS.

Roberts, Sam G.B. et al. 2009: Exploring variation in active network size: Constraints and ego characteristics. In: Social Networks 31,2: 138-146 [doi: 10.1016/j.socnet.2008.12.002].

Rusbult, Caryl E. 1983: A Longitudinal Test of the Investment Model: the Development (and deterioration) of Satisfaction and Commitment in Heterosexual Involvements. In: Journal of Personality and Social Psychology 45,1: 101-117 [doi: 10.1037/00223514.45.1.101].

Sauvain-Dugerdil, Claudine 2006: Soziodemografie der späten familialen Lebensphase. In: Eidgenössische Koordinationskommission für Familienfragen (Ed.): Pflegen, betreuen und bezahlen. Familien in späteren Lebensphasen: Bern. 37-71.

Schwartz, Joseph E. 1990: Penetrating Differentiation: Linking Macro and Micro Phenomena. In: Calhoun, Craig; Meyer, Marshall W.; Scott, Richard W. (Eds.): Structures of Power and Constraint: Papers in Honor of Peter M. Blau. Cambridge: Cambridge University Press: 353-374.

South, Scott J. 2001: Time-Dependent Effects of Wives' Employment on Marital Dissolution. In: American Sociological Review 66,2: 226-245 [doi: 10.2307/2657416].

South, Scott J.; Spitze, Glenna 1986: Determinants of Divorce Over the Marital Life Course. In: American Sociological Review 51,4: 583-590 [doi: 10.2307/2095590].

South, Scott J.; Lloyd, Kim M. 1995: Spousal Alternatives and Marital Dissolution. In: American Sociological Review 60,1: 21-35 [doi: 10.2307/2096343].

South, Scott J.; Trent, Katherine; Shen, Yang 2001: Changing Partners: Toward a Macrostructural-Opportunity Theory of Marital Dissolution. In: Journal of Marriage and the Family 63,3: 743-754 [doi: 10.1111/j.1741-3737.2001.00743.x].

Statistisches Bundesamt 2012: Fachserie 1: Bevölkerung und Erwerbstätigkeit. Reihe 1.1: Natürliche Bevölkerungsbewegung. Wiesbaden: Statistisches Bundesamt.

Stauder, Johannes 2006: Die Verfügbarkeit partnerschaftlich gebundener Akteure für den Partnermarkt. In: Kölner Zeitschrift für Soziologie und Sozialpsychologie 58,4: 617-637 [doi: 10.1007/s11577-006-0259-0].

Stauder, Johannes 2008: Opportunitäten und Restriktionen des Kennenlernens. Zur sozialen Vorstrukturierung der Kontaktgelegenheiten am Beispiel des Partnermarkts. In: Kölner Zeitschrift für Soziologie und Sozialpsychologie 60,2: 265-286 [doi: 10.1007/ s11577-008-0016-7].

Stauder, Johannes 2014a: The Social Structure of Opportunities for Contact and Interaction and Strategies for Analysing Friendship. In: Klein, Thomas et al. (Eds.): Der Partnermarkt und die Gelegenheiten des Kennenlernens. Der Partnermarktsurvey. Wiesbaden: Springer VS: 221-241.

Stauder, Johannes 2014b: Friendship Networks and the Social Structure of Opportunities for Contact and Interaction. In: Social Science Research 48C: 234-250 [doi: 10.1016/j.ssresearch.2014.06.004].

Svarer, Michae/ 2007: Working Late Do Workplace Sex Ratios Affect Partnership Formation and Dissolution? In: Journal of Human Resources 42,3: 582-595.

Udry, Richard J. 1981: Marital Alternatives and Marital Disruption. In: Journal of Marriage and the Family 43,4: 889-897 [doi: 10.2307/351345]. 
Wagner, Michae/ 1993: Soziale Bedingungen des Ehescheidungsrisikos aus der Perspektive des Lebenslaufs. In: Diekmann, Andreas; Weick, Stefan (Eds.): Der Familienzyklus als sozialer Prozess. Bevölkerungssoziologische Untersuchungen mit den Methoden der Ereignisanalyse. Berlin: Duncker \& Humblot: 372-393.

Wagner, Michael; Weiß, Bernd 2003: Bilanz der deutschen Scheidungsforschung. Versuch einer Meta-Analyse. In: Zeitschrift für Soziologie 32,1: 29-49.

Waite, Linda J.; Lillard, Lee A. 1991: Children and Marital Disruption. In: American Journal of Sociology 96,4: 930-953 [doi: 10.1086/229613].

White, Lynn K.; Booth, Alan 1991: Divorce Over the Life Course. In: Journal of Family Issues 12,1: 5-21 [doi: 10.1177/019251391012001002].

Woll, Anke; Häring, Armando; Stoye, Kristian 2014: Das Erhebungsinstrument des Partnermarktsurvey. In: Häring, Armando et al. (Eds.): Der Partnermarkt und die Gelegenheiten des Kennenlernens. Der Partnermarktsurvey. Wiesbaden: VS Verlag: 23-44.

Wu, Zheng; Penning, Margaret J. 1997: Marital instability after midlife. In: Journal of Family Issues 18,5: 459-478 [doi: 10.1177/019251397018005001].

Dr. Ingmar Rapp $(\bowtie)$, Prof. Dr. Thomas Klein, Sebastian Fronk, Dr. Johannes Stauder. Max-Weber-Institut für Soziologie, Universität Heidelberg. Heidelberg. Germany.

E-Mail: ingmar.rapp@soziologie.uni-heidelberg.de thomas.klein@soziologie.uni-heidelberg.de sebastian.fronk@soziologie.uni-heidelberg.de johannes.stauder@soziologie.uni-heidelberg.de

URL: http://www.soz.uni-heidelberg.de/Dr_Ingmar_Rapp/820,621,0,0,1.html http://www.soz.uni-heidelberg.de/Prof_Dr_Thömas_Klein/820,488,0,0,1.html http://www.soz.uni-heidelberg.de/DiplS̄owi_Sebastian_Fronk/820,713,0,0,1.html http://www.soz.uni-heidelberg.de/Dr_Johannes_Stauder/820,573,0,0,1.html 


\section{Comparative Population Studies}

WWW.comparativepopulationstudies.de

ISSN: 1869-8980 (Print) - 1869-8999 (Internet)

Published by / Herausgegeben von

Prof. Dr. Norbert F. Schneider

Federal Institute for Population Research

D-65180 Wiesbaden / Germany

\section{Managing Editor /}

Verantwortlicher Redakteur

Frank Swiaczny

\section{Assistant Managing Editor /}

\section{Stellvertretende Redakteurin}

Katrin Schiefer

\section{Copy Editor (German) /}

Lektorat (deutsch)

Dr. Evelyn Grünheid

\section{Layout / Satz}

Beatriz Feiler-Fuchs

E-mail:cpos@bib.bund.de

\section{Scientific Advisory Board /}

Wissenschaftlicher Beirat

Paul Gans (Mannheim)

Johannes Huinink (Bremen)

Michaela Kreyenfeld (Rostock)

Marc Luy (Wien)

Clara H. Mulder (Groningen)

Notburga Ott (Bochum)

Peter Preisendörfer (Mainz)

Zsolt Spéder (Budapest)
Board of Reviewers / Gutachterbeirat Martin Abraham (Erlangen)

Laura Bernardi (Lausanne)

Hansjörg Bucher (Bonn)

Claudia Diehl (Konstanz)

Andreas Diekmann (Zürich)

Gabriele Doblhammer-Reiter (Rostock)

Jürgen Dorbritz (Wiesbaden)

Anette Eva Fasang (Berlin)

E.-Jürgen Flöthmann (Bielefeld)

Alexia Fürnkranz-Prskawetz (Wien)

Beat Fux (Salzburg)

Joshua Goldstein (Berkeley)

Karsten Hank (Köln)

Sonja Haug (Regensburg)

Hill Kulu (Liverpool)

Aart C. Liefbroer (Den Haag)

Kurt Lüscher (Konstanz)

Emma Lundholm (Umeå)

Nadja Milewski (Rostock)

Dimiter Philipov (Wien)

Roland Rau (Rostock)

Tomáš Sobotka (Wien)

Jeroen Spijker (Barcelona)

Olivier Thévenon (Paris)

Helga de Valk (Brussel)

Heike Trappe (Rostock)

Michael Wagner (Köln) 